\title{
Lactose intolerance and bone mass in postmenopausal Italian women
}

\author{
BY GINO R. CORAZZA ${ }^{1}$, GIUSEPPE BENATI ${ }^{2}$, ANTONIO DI SARIO ${ }^{2}$, \\ CARLO TAROZZI ${ }^{3}$, ALESSANDRA STROCCHI ${ }^{2}$, MARIO PASSERI ${ }^{4}$ \\ AND GIOVANNI GASBARRINI ${ }^{2}$ \\ ${ }^{1}$ Department of Internal Medicine, University of L'Aquila, L'Aquila, Italy \\ ${ }^{2}$ Department of Medical Pathology, University of Bologna, Bologna, Italy \\ ${ }^{3}$ Division of Nuclear Medicine, Ospedale Maggiore, Bologna, Italy \\ ${ }^{4}$ Department of Medicine, University of Parma, Parma, Italy
}

(Received 14 February 1994-Revised 20 May 1994 - Accepted 24 June 1994)

\begin{abstract}
Previous studies on the role of lactose malabsorption in the pathogenesis of postmenopausal osteoporosis have yielded conflicting results and further information is needed. To date, all studies have been carried out on populations with a low prevalence of lactose malabsorption and the lactose intestinal absorptive capacity was tested using a non-physiological dose of lactose. In fifty-eight Italian postmenopausal women (mean age 57 (SD 7) years), bone mineral density (BMD) at lumbar spine, $\mathrm{H}_{2}$ breath response after ingestion of $20 \mathrm{~g}$ lactose, intensity of symptoms of intolerance after a lactose load and daily $\mathrm{Ca}$ intake were evaluated. No differences were found between women with or without a positive $\mathrm{H}_{2}$ breath test with regard to BMD (-1.2 (SD 0.9) v. -0.9 (SD 0.8)) and Ca intake (509 (SD 266) v. 511 (SD 313) $\mathrm{mg} / \mathrm{d})$. On the contrary, hoth BMD and $\mathrm{Ca}$ intake were significantly lower in women with lactose malabsorption and symptoms of intolerance $(-1.5$ (SD 0.7$)$ and 378 (SD 220) $\mathrm{mg} / \mathrm{d}$ ) than in those with malabsorption without symptoms (-0.9 (SD 0.9) and 624 (SD 254) $\mathrm{mg} / \mathrm{d}$ ). Moreover, in lactose malabsorbers $\mathrm{Ca}$ intake was correlated inversely with symptom score $\left(r_{s}-0.31, P<0.05\right)$ and positively with BMD $\left(r_{s}, 0.42, P<0.005\right)$. Our results show that in Italian postmenopausal women $C a$ intake and BMD are not influenced directly by lactose malabsorption; the appearance of symptoms of intolerance seems to influence BMD unfavourably through a reduced $\mathrm{Ca}$ intake.
\end{abstract}

Calcium: $\mathbf{H}_{2}$ breath test: Lactose: Osteoporosis: Postmenopausal women

Osteoporosis is extremely common among postmenopausal women. Its aetiology is multifactorial (Dempster \& Lindsay, 1993) and, although the reduction in plasma levels of oestrogens represents the main pathogenetic factor (Richelson et al. 1984), not all menopausal women develop osteoporosis (Riggs \& Melton, 1990). This implies that other factors are involved, and amongst these the importance of dietary $\mathrm{Ca}$ intake has been emphasized (Dawson-Hughes et al. 1987; Andon et al. 1991).

Lactose malabsorption, caused by primary late-onset lactase $(E C 3.2 .1 .23)$ deficiency, may lead to the onset of abdominal symptoms and consequently induce the avoidance of milk and milk products from the diet (Birge et al. 1967; Newcomer $e t$ al. 1978a). Since these foodstuffs provide about two-thirds of the dietary requirement of Ca (Birge et al. 1967; Newcomer et al. 1978 a) lactose malabsorption has been suggested as a predisposing factor to osteoporosis (Birge et al. 1967; Newcomer et al. 1978 a; Finkenstedt et al. 1986; Horowitz et al. 1987; Vigorita et al. 1987). However, other studies have failed to show a clear relationship between these two conditions (Alhava et al. 1987; Jodry et al. 1987; Härmä \& Alhava, 1988; Slemenda et al. 1991). These discrepancies could depend on the different 
methods used to evaluate lactose malabsorption and osteoporosis and the different criteria used to recruit the patients.

All these studies were carried out in populations with a low prevalence of lactose malabsorption (Scrimshaw \& Murray, 1988) and their results may not be applicable, therefore, to populations with a higher prevalence of lactose malabsorption, such as the Italian population (Burgio et al. 1984; Bozzani et al. 1986). Moreover, since all studies were performed with a non-physiological dose of lactose (50 g or more; Bayless, 1981; Rosado \& Solomons, 1983; Smith et al. 1985), their findings need to be confirmed by testing the intestinal absorptive capacity with a more physiological dose of this carbohydrate.

\section{PATIENTS AND METHODS}

\section{Patients}

Eighty-three consecutive postmenopausal women (mean age 57 (SD 7) years) suspected of having osteoporosis because of back pain, all Caucasian from the Bologna area, were recruited. Twenty-five patients were excluded from the study for the following reasons: ovariectomy ( $n$ 6), oestrogen replacement therapy ( $n$ 6), Ca supplementation $(n 5)$, gastrointestinal diseases $(n 4)$, recent treatment with antibiotics or drugs which could modify the intestinal flora $(n 4)$. The fifty-eight women included in the study were free of diseases known to influence $\mathrm{Ca}$ and bone metabolism.

Informed consent was obtained from all the subjects taking part in the study.

\section{Bone mass measurement}

Bone mineral density (BMD) was measured in each patient at the lumbar spine region (L2L4) by dual-photon absorptiometry (Norland DBD 2600, Norland Co., WI, USA), and BMD values were expressed as Z-scores, which indicate the deviation from the average expected sex- and age-matched BMD value in SD units, and normalize the raw data for sexand age-dependent variation in BMD (Seeman et al. 1982). Since the relative risk of fracture in women increases by a factor of about 2 for each SD decrease in BMD (Johnston et al. 1989), diagnosis of osteoporosis was made in those women whose BMD was $1 \mathrm{SD}$ below the mean values for healthy female control subjects.

\section{Diet history}

All patients were asked about their awareness of a relationship between the onset of abdominal symptoms, such as meteorism, flatulence, abdominal pain, diarrhoea and the intake of milk, ice cream, cheese and yoghurt.

Daily $\mathrm{Ca}$ intake was evaluated in each patient by completing a dietary diary for three consecutive days (two weekdays and one weekend day) listing all the food eaten and the respective quantities, evaluated on the basis of usual portion sizes (Hankin, 1989). The diaries were then checked by one of the authors who was unaware of the clinical details of the patients and analysed on the basis of food-composition tables provided by the Italian National Institute of Nutrition (Istituto Italiano della Nutrizione, 1983).

\section{Hydrogen breath testing}

Alveolar breath samples were collected before and every $30 \mathrm{~min}$ for $4 \mathrm{~h}$ after the ingestion of a $100 \mathrm{ml}$ solution containing $20 \mathrm{~g}$ lactose (Corazza et al. 1990). To minimize basal $\mathrm{H}_{2}$ excretion, all the subjects taking part in the study ate a meal of rice and meat the evening before the test (Kotler et al. 1982) and then fasted for the next $12 \mathrm{~h}$. End-alveolar breath samples were collected using a commercial device (AlveoSampler; Quintron Instruments, Milwaukee, WI, USA). Measurement of $\mathrm{H}_{2}$ concentration was performed using a 


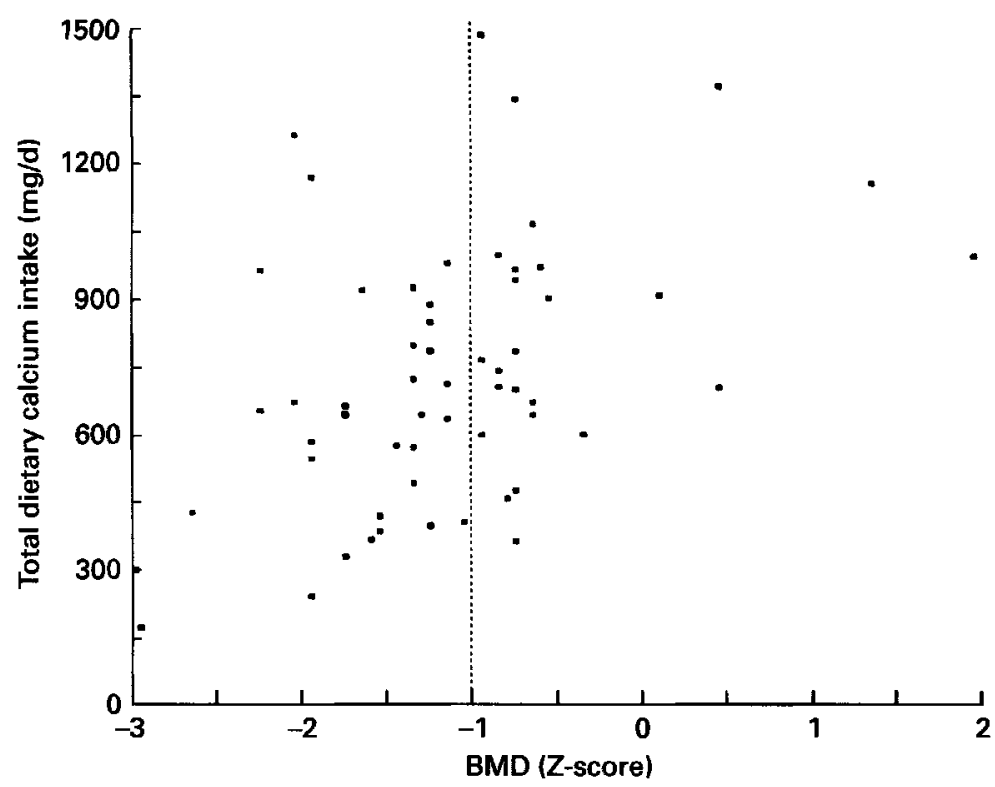

Fig. 1. Correlation between total dietary calcium intake and bone mineral density (BMD) in fifty-eight Italian postmenopausal women. (---), Separates women with osteoporosis (left) from those without osteoporosis (right). For details of subjects and procedures, see pp. 480-481. $r_{s} 0 \cdot 40, P<0.002$.

Microlyzer 12 gas-liquid chromatograph (Quintron Instruments). The chromatograph was calibrated with a standard gas mixture containing $102 \mu 1 \mathrm{H}_{2} / 1$. An increase in breath $\mathrm{H}_{2}$ concentration $\geqslant 20 \mathrm{ppm}$ above the baseline value was considered indicative of lactose malabsorption (Kotler et al. 1982; Corazza et al. 1990). During the $8 \mathrm{~h}$ after lactose ingestion, patients were asked to record the appearance of symptoms of intolerance (meteorism, flatulence, abdominal pain, diarrhoea) in a personal diary, indicating the intensity of each symptom with the following scores: absent 0 , mild 1 , moderate 2 , severe 3; diarrhoea was always scored as 3 (Rosado et al. 1984). Each diary was examined blindly by a physician who, on the basis of the partial scores, calculated a cumulative index.

\section{Statistical analysis}

Data were expressed as means and standard deviations and statistical comparisons were performed using Spearman's rank correlation coefficient, Mann Whitney U test, and Fisher's exact probability test.

\section{RESULTS}

Fig. 1 shows total dietary Ca intake and BMD for the fifty-eight postmenopausal women studied. A significant $(P<0.002)$ positive correlation between these two variables is evident. Thirty-three of the fifty-eight women $(57 \%)$ studied had a BMD 1 sD below the mean values for healthy female control subjects and, therefore, were considered to have osteoporosis. The mean age of women with osteoporosis (58 (SD 7) years) was not significantly different from that of the women without osteoporosis (57 (SD 7) years).

The prevalence of women aware of being intolerant to milk and milk products in the osteoporotic group (58\%) was not significantly different from that of the non-osteoporotic group ( $40 \%$ ). Fig. 2 shows that no significant differences were found, with respect to BMD and $\mathrm{Ca}$ intake from milk and milk products, between women unaware of being intolerant 


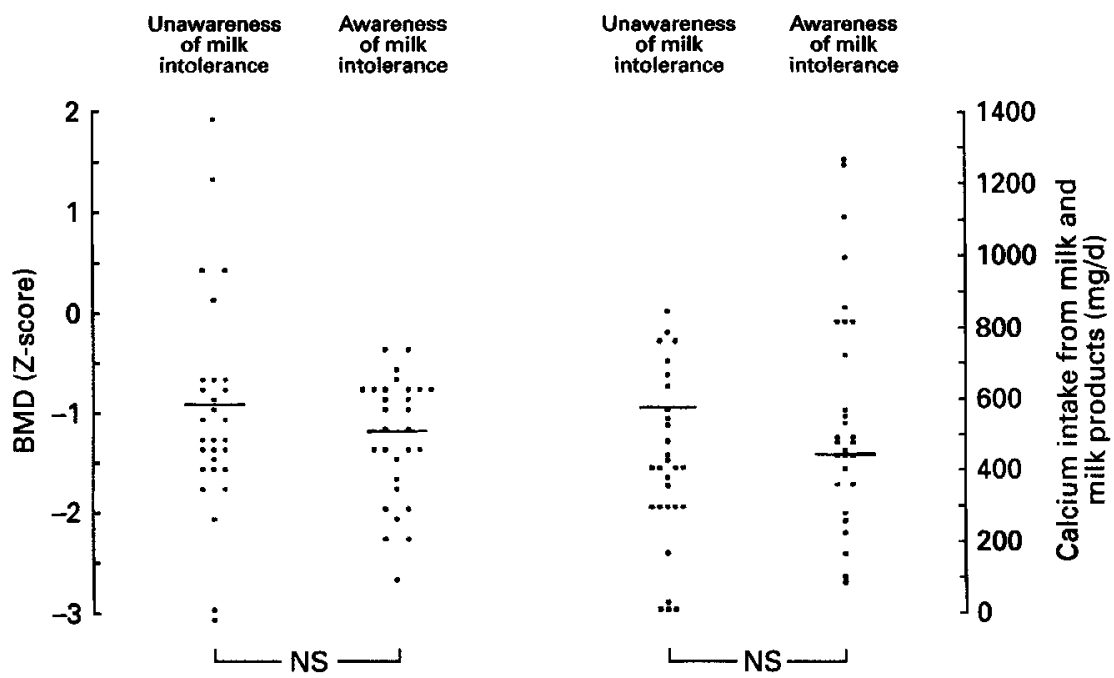

Fig. 2. Bone mineral density (BMD) and calcium intake from milk and milk products in fifty-eight Italian postmenopausal women who were unaware and aware of being intolerant to milk and milk products. For details of subjects and procedures, see pp. $480-481$. NS, not significant.

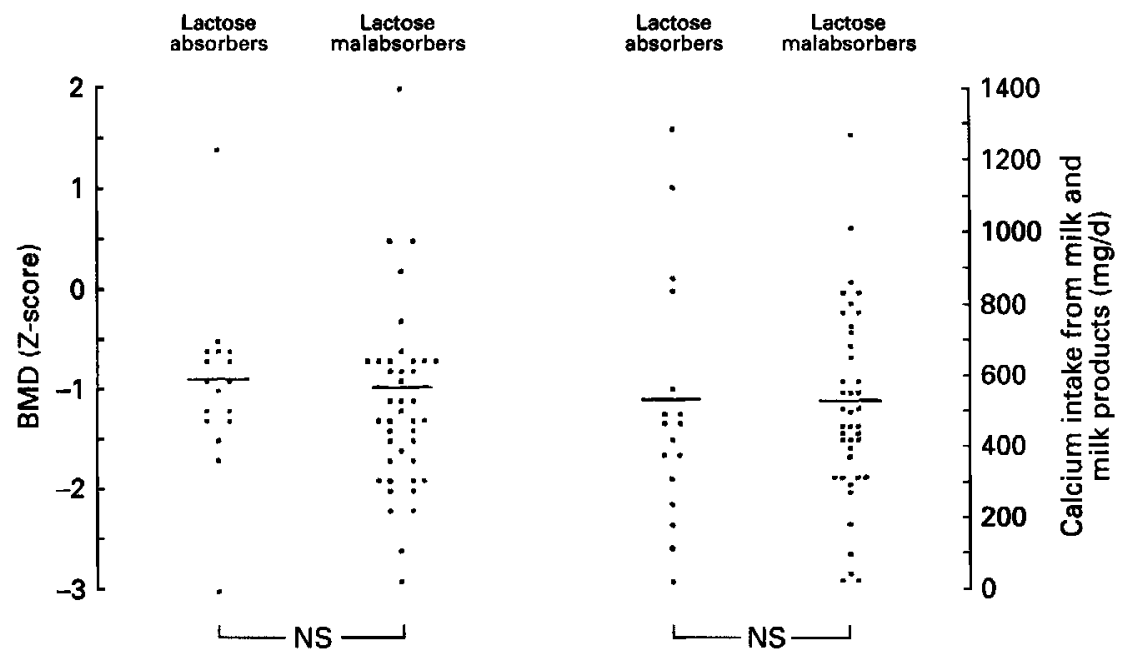

Fig. 3. Bone mineral density (BMD) and calcium intake from milk and milk products in fifty-eight Italian post menopausal women who were lactose absorbers and malabsorbers. For details of subjects and procedures, see pp. $480-481$. NS, not significant.

to milk and milk products ( $-1 \cdot 2$ (SD 0.6 ) and 579 (SD 319) $\mathrm{mg} / \mathrm{d}$ respectively) and women aware of being intolerant ( -0.9 (SD 1.1$)$ and 441 (SD 238$) \mathrm{mg} / \mathrm{d}$ respectively).

Measurement of $\mathrm{H}_{2}$ response after the ingestion of $20 \mathrm{~g}$ lactose showed that $76 \%$ of the osteoporotic women and $64 \%$ of the non-osteoporotic women were lactose malabsorbers; there was no significant difference between these two values. Fig. 3 shows that there were no differences with respect to BMD and $\mathrm{Ca}$ intake from milk and milk products between lactose absorbers ( -0.9 (SD 0.8) and 511 (SD 313) $\mathrm{mg} / \mathrm{d}$ respectively) and malabsorbers $(-1.2$ (SD 0.9) and 509 (SD 266) $\mathrm{mg} / \mathrm{d}$ respectively).

The prevalence of lactose malabsorbers with symptoms of intolerance in the $8 \mathrm{~h}$ 


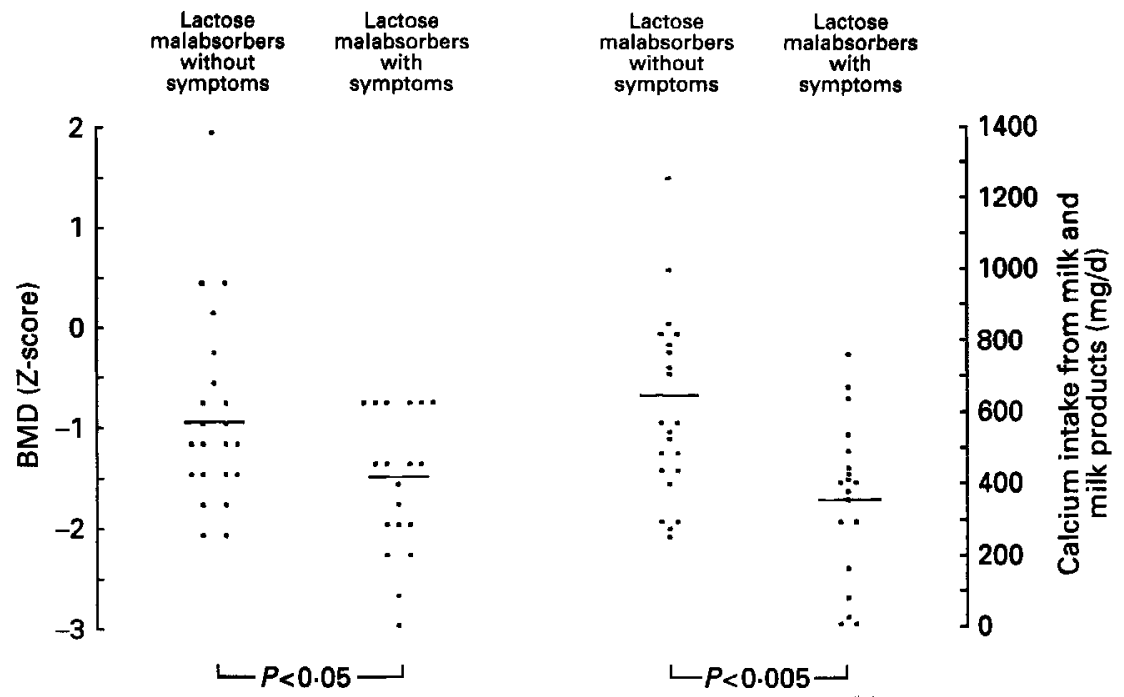

Fig. 4. Bone mineral density (BMD) and calcium intake from milk and milk products in fifty-eight Italian postmenopausal women who were lactose malabsorbers without and with symptoms of intolerance in the $8 \mathrm{~h}$ after lactose ingestion. For details of subjects and procedures, see pp. $480-481$.
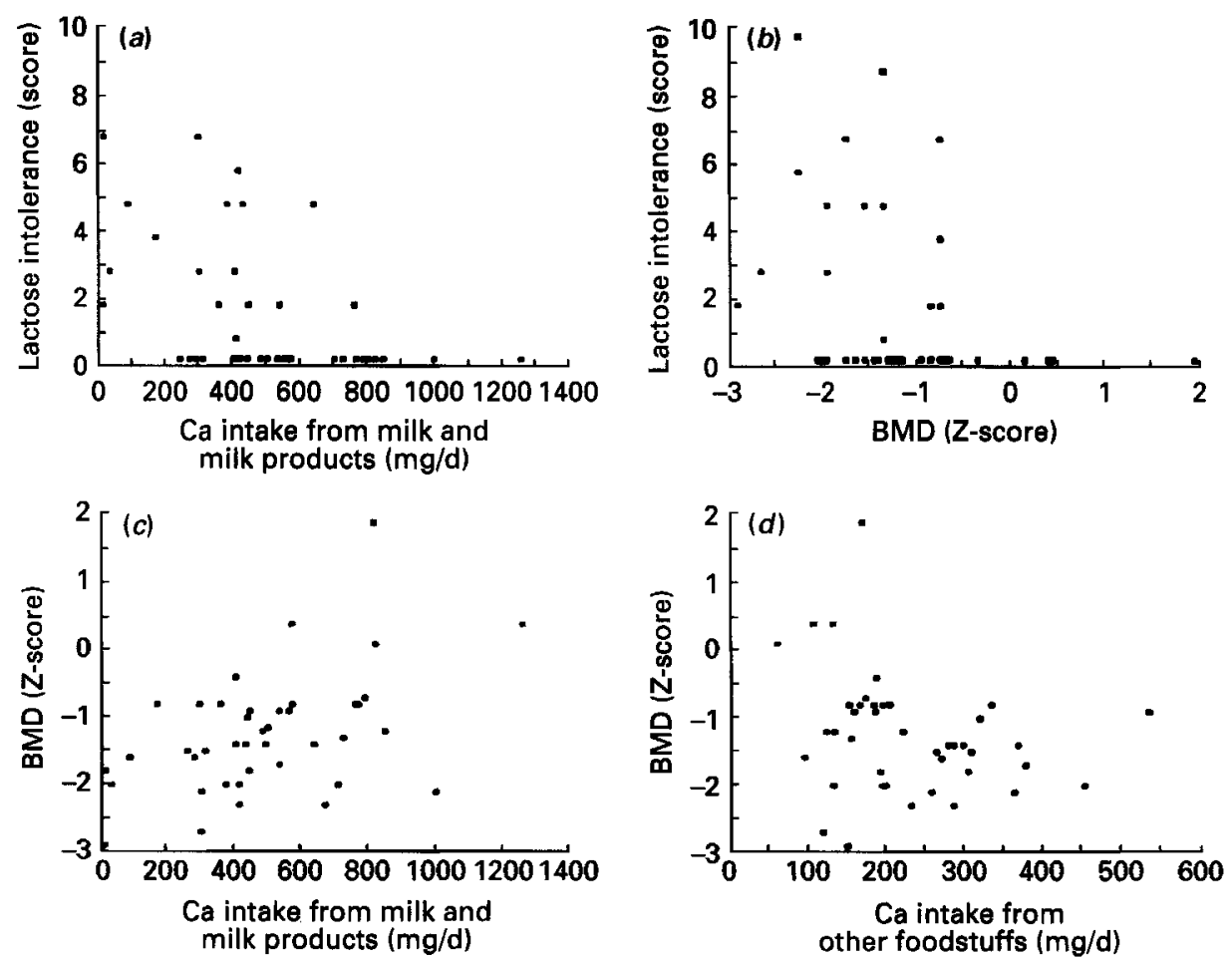

Fig. 5. Correlations between symptom score of intolerance and (a) calcium intake from milk and milk products $\left(r_{s}-0.31, P<0.05\right)$ and (b) bone mineral density (BMD; $r_{s}-0 \cdot 16$, not significant), and between BMD and Ca intake from (c) milk and milk products $r_{s} 0.42, P<0.005$ and (d) from other foodstuffs $\left(r_{s} 0.23\right.$, not significant) in Italian postmenopausal women who were lactose malabsorbers. For details of subjects and procedures, see pp. $480-481$. 
following carbohydrate ingestion did not differ significantly between osteoporotic (39\%) and non-osteoporotic women (24\%). Fig. 4 shows that in lactose malabsorbers with symptoms of intolerance both BMD and Ca intake from milk and milk products $(-1.5$ (SD $0.7)$ and 378 (SD 220$) \mathrm{mg} / \mathrm{d}$ respectively) were significantly lower $(P<0.05$ and $P<0.005$ respectively) than those in malabsorbers without symptoms $(-0.9$ (SD 0.9$)$ and 624 (SD 254) $\mathrm{mg} / \mathrm{d}$ respectively).

Fig. 5 shows that in women with a positive $\mathrm{H}_{2}$ breath test for lactose malabsorption the symptom score of intolerance correlated negatively with $\mathrm{Ca}$ intake from milk and milk products $(P<0.05)$ but did not correlate with BMD. BMD, in turn, was correlated positively with $\mathrm{Ca}$ intake from milk and milk products $(P<0 \cdot 005)$ but not with $\mathrm{Ca}$ intake from other foodstuffs.

\section{DISCUSSION}

It is well known that in postmenopausal women an adequate $\mathrm{Ca}$ intake causes a positive shift in Ca balance (Heaney et al. 1978) and suppresses biochemical indices of bone resorption (Horowitz et al. 1984). Moreover, inadequate $\mathrm{Ca}$ intake might be associated with low BMD, although this relationship has been confirmed by some authors (DawsonHughes et al. 1987; Andon et al. 1991) but not by others (Riggs et al. 1987; Angus et al. 1988). The reasons for these discrepancies could depend on the different methods used to evaluate the dietary intake of $\mathrm{Ca}$. We used a $3 \mathrm{~d}$ diet record (Hankin, 1989), with similar precision to that of a $7 \mathrm{~d}$ diet record (Payette \& Gray-Donald, 1991), which is considered the 'gold standard' in evaluating Ca intake (Cummings et al. 1987). In a vast group of menopausal women this method confirmed that a highly significant correlation exists between total $\mathrm{Ca}$ intake and BMD.

Since lactose malabsorption might cause a marked reduction in milk and milk-product consumption (Bayless, 1981), which together provide most of the $\mathrm{Ca}$ in the diet (Birge et al. 1967; Newcomer et al. 1978a), the relationship between lactose malabsorption and postmenopausal osteoporosis has been extensively studied (Birge et al. 1967; Alhava et al. 1977; Newcomer et al. 1978 a; Finkenstedt et al. 1986; Horowitz et al. 1987; Jodry et al. 1987; Vigorita et al. 1987; Härmä \& Alhava, 1988; Slemenda et al. 1991). In some of these studies (Newcomer et al. 1978 a; Horowitz et al. 1987; Vigorita et al. 1987) this relationship was confirmed by the finding of a higher prevalence of lactose malabsorbers in osteoporotic than in non-osteoporotic women. In all previous studies prevalence of lactose malabsorbers range from $26 \%$ (Newcomer et al. 1978a) to $65 \%$ (Vigorita et al. 1987) in osteoporotic women and from 0\% (Birge et al. 1967) to 20\% (Härmä \& Alhava, 1988) in nonosteoporotic women. Compared with these values our prevalence value was much higher both in osteoporotic (76\%) and non-osteoporotic women $(64 \%)$. This result confirms previous findings of a high prevalence of primary late-onset lactase deficiency in the Italian population (Burgio et al. 1984; Bozzani et al. 1986), and could explain the absence of a statistically significant difference between osteoporotic and non-osteoporotic women. In some of the previous studies (Newcomer et al. 1978a; Horowitz et al. 1987; Vigorita et al. 1987) the lower $\mathrm{Ca}$ intake found in lactose malabsorbers than in absorbers was attributed to the avoidance of milk and milk products due to lactose malabsorption. Unlike these studies (Newcomer et al. 1978a; Horowitz et al. 1987; Vigorita et al. 1987), but in agreement with others (Jodry et al. 1987; Härmä \& Alhava, 1987; Slemenda et al. 1991), our results show that lactose malabsorption alone is not sufficient to induce a spontaneous avoidance of milk and milk products and, therefore, does not affect bone mass. It is clear that the true culprit for the avoidance of lactose-related foods from the diet is not malabsorption itself but intolerance due to malabsorption of this carbohydrate. Lactose malabsorption, in fact, does not always lead to intolerance (Newcomer, 1981; Rosado et 
al. 1987; Johnson et al. 1993). There are various explanations for this discrepancy: the variability in the individual's perception of symptoms (Jones et al. 1976; Gudmand-Hoyer et al. 1977), the ability of the colon to absorb short-chain fatty acids derived from the bacterial fermentation of malabsorbed lactose (Bond et al. 1980), $\mathrm{H}_{2}$ consumption by colonic methanogenic bacteria (Strocchi \& Levitt, 1992) and/or reduced colonic $\mathrm{pH}$ (Perman et al. 1981) which could lead to a significant decrease in volume of colonic gas, and the possible induction of colonic bacterial lactase by lactose malabsorption (Saavedra \& Perman, 1989).

Although some authors (Härmä \& Alhava, 1988; Slemenda et al. 1991) had already reported the importance of relating osteoporosis to lactose intolerance, this relationship was never studied. It has been demonstrated that patients' awareness of a previous milk intolerance cannot predict either lactose absorptive status or the occurrence of symptoms after lactose load (Di Palma \& Narvaez, 1988). In agreement with these results, we show that this awareness does not significantly affect either $\mathrm{Ca}$ intake from milk and milk products or BMD, confirming the unreliability of previous convictions of the patients in relation to their food-symptom relationship (Ferguson, 1990).

Since the appearance of symptoms of intolerance is related to the dose of lactose ingested (Newcomer et al. 1978 b), we evaluated malabsorption and the occurrence of abdominal symptoms after administration of a watery solution containing 20 and not $50 \mathrm{~g}$ lactose. It is conceivable that malabsorption of $50 \mathrm{~g}$ lactose doses not permit compensation, by the above-mentioned mechanisms, sufficient to prevent the onset of intolerance symptoms. It can be presumed, therefore, that in those studies in which malabsorption alone was significantly associated with osteoporosis (Birge et al. 1967; Newcomer et al. 1978a; Finkenstedt et al. 1986; Horowitz et al. 1987; Vigorita et al. 1987), lactose malabsorption was more frequently accompanied by intolerance, specifically because of the doses of carbohydrate used. Their main pitfall, however, is the fact that their experimental conditions were far removed from what occurs in real life. In other words, we are not sure that these subjects would have really experienced symptoms of intolerance after a more physiological lactose dose and if, precisely for this reason, they did in fact tend to avoid lactose-containing products.

The low $\mathrm{Ca}$ intake found in women with a low BMD could be attributed to many other factors, and not to lactose intolerance only. However, we have shown that in lactose malabsorbers with symptoms, $\mathrm{Ca}$ intake from milk and milk products correlates inversely with the degree of intolerance and positively with BMD. These results, therefore, suggest that lactose malabsorption and intolerance do have a role in the pathogenesis of postmenopausal osteoporosis. Otherwise, it was expected that in such a typically multifactorial disease the extent of bone loss would not correlate with the degree of lactose intolerance: lactose intolerance would represent a cofactor and not 'the aetiological factor' of postmenopausal osteoporosis.

In the past the association between lactase deficiency and osteoporosis had been questioned because American blacks, in whom lactose malabsorption is common (Cuatrecasas et al. 1965), had a lower incidence of osteoporosis than whites (Cohn et al. 1977). This discrepancy could be explained not only by the differences in the initial bone mass (Cohn et al. 1977), or in other factors such as the resistance to the bone resorptive effects of parathyroid hormone and 1,25-dihydroxycholecaliferol (Bell et al. 1985) or the rate of bone remodelling (Weinstein \& Bell, 1988) or, perhaps, physical activity, but also by a greater lactose tolerance of hypolactasic blacks (Cuatrecasas $e t$ al. 1965), and this is totally in accordance with our findings.

In conclusion, the present study shows that when lactose malabsorption is accompanied by symptoms of intolerance it represents a risk factor for postmenopausal osteoporosis. 
From a practical point of view, when lactose malabsorption causes the onset of symptoms of intolerance, $\mathrm{Ca}$ intake must be supplemented either pharmacologically or with the intake of less-harmful milk products, such as yoghurt (Kolars et al. 1984), and/or with the addition to milk of exogenous lactases (Rosado et al. 1984; Corazza et al. 1992).

\section{REFERENCES}

Alhava, E. M., Jussila, J., Karjalainen, P. \& Vuojolahti, P. (1977). Lactose malabsorption and bone mineral content. Acta Medica Scandinavica 201, 281-283.

Andon, M. B., Smith, K. T., Bracker, M., Sartoris, D., Saltman, P. \& Strause, L. (1991). Spinal bone density and calcium intake in healthy postmenopausal women. American Journal of Clinical Nutrition 54, $927-929$.

Angus, R. M., Sambrook, P. N., Pocock, N. A. \& Eisman, J. A. (1988). Dietary intake and bone mineral density Bone Mineral 41, 265-277.

Bayless, T. M. (1981). Lactose malabsorption, milk intolerance and symptom awareness in adults. In Lactose Digestion, Clinical and Nutritional Implications, pp. 117-123 [D. M. Page and T. M. Bayless, editors]. Baltimore: Johns Hopkins University Press.

Bell, N. H., Greene, A., Epstein, S., Oexmann, M. J., Show, S. \& Shary, J. (1985). Evidence for alteration of the vitamin D-endocrine system in Blacks. Journal of Clinical Investigation 76, 470-473.

Birge, S. J., Keutmann, H. T., Cuatrecasas, P. \& Whedon, G. D. (1967). Osteoporosis, intestinal lactase deficiency and low dietary calcium intake. New England Journal of Medicine 276, 445-448.

Bond, J. H., Currier, B. E., Buchwald, H. \& Levitt, M. D. (1980). Colonic conservation of malabsorbed carbohydrate. Gastroenterology 78, $444-447$.

Bozzani, A., Penagini, R., Velio, G., Camboni, G., Corbellini, A., Quatrini, M., Conte, D. \& Bianchi, P. A. (1986). Lactose malabsorption and intolerance in Italians. Clinical implications. Digestive Diseases and Sciences 31, $1313-1316$.

Burgio, G. R., Flatz, G., Barbera, C., Patanè, R., Boner, A., Cajozzo, C. \& Flatz, S. D. (1984). Prevalence of primary adult lactose malabsorption and awareness of milk intolerance in Italy. American Journal of Clinical Nutrition 39, 100-104.

Cohn, S. H., Abesamis, C., Yasumara, S., Aloia, J. F., Zanzi, I. \& Ellis, K. J. (1977). Comparative skeletal mass and radial bone mineral content in black and white women. Metabolism 26, 171-178.

Corazza, G. R., Benati, G., Sorge, M., Strocchi, A., Calza, G. \& Gasbarrini, G. (1992). $\beta$-Galactosidase from Aspergillus niger in adult lactose malabsorption: a double-blind crossover study. Alimentary Pharmacology \& Therapeutics 6, 61-66.

Corazza, G. R., Sorge, M., Strocchi, A., Lattanzi, M. C., Benati, G. \& Gasbarrini, G. (1990). Methodology of the $\mathrm{H}_{2}$ breath test. II. Importance of the test duration in the diagnosis of carbohydrate malabsorption. Italian Journal of Gastroenterology 22, 303-305.

Cuatrecasas, P., Lockwood, D. \& Caldwell, J. R. (1965). Lactase deficiency in adult: common occurence. Lancet i, 14-18.

Cummings, S. R., Block, G., McHenry, K. \& Baron, R. B. (1987). Evaluation of two food frequency methods of measuring dietary calcium intake. American Journal of Epidemiology 126, 796-802.

Dawson-Hughes, B., Jacques, P. \& Shipp, C. (1987). Dietary calcium intake and bone loss from the spine in healthy postmenopausal women. American Journal of Clinical Nutrition 46, 685-687.

Dempster, D. W. \& Lindsay, R. (1993). Pathogenesis of osteoporosis. Lancet 341, 797-801.

Di Palma, J. A. \& Narvaez, R. M. (1988). Prediction of lactose malabsorption in referral patients. Digestive Diseases and Sciences 33, 303-307.

Ferguson, A. (1990). Food sensitivity or self-deception? New England Journal of Medicine 16, 476-478.

Finkenstedt, G., Skrabal, F., Gasser, R. W. \& Braunsteiner, H. (1986). Lactose malabsorption, milk consumption, and fasting blood glucose concentrations in women with idiopathic osteoporosis. British Medical Journal 292, $161-162$.

Gudmand-Höyer, E. \& Simony, K. (1977). Individual sensitivity to lactose in lactose malabsorption. Digestive Diseases 22, 177-181.

Hankin, J. H. (1989). Development of a diet history questionnaire for studies of old persons. American Journal of Clinical Nutrition 50, 1121-1127.

Härmä, M. \& Alhava, E. (1988). Is lactose malabsorption a risk factor in fractures of the elderly? Annales Chirurgiae Gynaecologiae 77, 180-183.

Heaney, R. P., Recker, R. R. \& Saville, P. D. (1978). Menopausal changes in calcium balance performance. Journal of Laboratory and Clinical Medicine 92, 953-963.

Horowitz, M., Need, A. G., Philcox, J. C. \& Nordin, B. E. C. (1984). Effect of calcium supplementation on urinary hydroxyproline in osteoporotic postmenopausal women. American Journal of Clinical Nutrition 39 , $857-859$.

Horowitz, M., Wishart, J., Mundy, L. \& Nordin, B. E. C. (1987). Lactose and calcium absorption in postmenopausal osteoporosis. Archives of Internal Medicine 147, 534-536. 
Istituto Italiano della Nutrizione (1983). Tabelle di Composizione Degli Alimenti. Roma: Istituto Italiano della Nutrizione.

Jodry, H., Griessen, M., Courvoisier, B. \& Fischer, J. (1987). Incidence de la dèficience en lactase chez les patientes atteintes d'ostèoporose d'involution et chez les sujets normaux (Incidence of lactase deficiency in osteoporotic patients and healthy subjects). Schweizerische Medizinische Wochenschrift 117, 1736-1741.

Johnson, A. O., Semenya, J. G., Buchowski, M. S., Enwonwu, C. O. \& Scrimshaw, N. S. (1993). Correlation of lactose maladigestion, lactose intolerance, and milk intolerance. American Journal of Clinical Nutrition 57, $399-401$.

Johnston, C. C., Melton, L. J., Lindsay, R. \& Eddy, D. M. (1989). Clinical indications for bone mass measurement. Journal of Bone and Mineral Research 4 Suppl. 2, 1-28.

Jones, D. V., Latham, M. C., Kosikowscki, F. W. \& Woodward, G. (1976). Symptom response to lactose reduced milk in lactose intolerant adults. American Journal of Clinical Nutrition 29, 633.

Kolars, J. C., Levitt, M. D., Aouji, M. \& Savaiano, D. A. (1984). Yogurt - an autodigesting source of lactose. New England Journal of Medicine 310, 1-3.

Kotler, D. P., Holt, P. R. \& Rosensweig, N. S. (1982). Modification of the breath hydrogen test: increased sensitivity for the detection of the carbohydrate malabsorption. Journal of Laboratory and Clinical Medicine 100, 798-805.

Newcomer, A. D. (1981). Immediate symptomatic and long-term nutritional consequences of hypolactasia. In Lactose Digestion, Clinical and Nutritional Implications, pp. 124-133 [D. M. Page and T. M. Bayless, editors]. Baltimore: Johns Hopkins University Press.

Newcomer, A. D., Hodgson, S. F., McGill, D. B. \& Thomas, P. J. (1978a). Lactase deficiency: prevalence in osteoporosis. Annals of Internal Medicine 89, 218-220.

Newcomer, A. D., McGill, D. B., Thomas, P. J. \& Hofmann, A. F. (1978b). Tolerance to lactose among lactasedeficient American Indians. Gastroenterology 74, 44-46.

Payette, H. \& Gray-Donald, K. (1991). Dietary intake and biochemical indices of nutritional status in an elderly population, with estimates of the precision of the 7-d food record. American Journal of Clinical Nutrition 54, $478-488$.

Perman, J. A., Modler, S. \& Obson, A. C. (1981). Role of pH in production of hydrogen from carbohydrate by colonic bacterial flora. Journal of Clinical Investigation 67, 643-650.

Richelson, L. S., Wahner, H. W., Melton, L. J. \& Riggs, B. L. (1984). Relative contributions of aging and estrogen deficiency to postmenopausal bone loss. New England Journal of Medicine 311, 1273-1275.

Riggs, B. L., Wahner, H. W., Melton, J., Richelson, L. S., Judd, H. L. \& O'Fallon, W. M. (1987). Dietary calcium intake and rates of bone loss in women. Journal of Clinical Investigation 80, 979-982.

Riggs, B. L. \& Melton, L. J. (1990). Clinical heterogeneity of involutional osteoporosis: implications for preventive therapy. Journal of Clinical Endocrinology and Metabolism 70, 1229-1232.

Rosado, J. L., Allen, L. H. \& Solomons, N. W. (1987). Milk consumption, symptom response, and lactose digestion in milk intolerance. American Journal of Clinical Nutrition 45, 1457-1460.

Rosado, J. L. \& Solomons, N. W. (1983). Sensitivity and specificity of the hydrogen breath-analysis test for detecting malabsorption of physiological doses of lactose. Clinical Chemistry 29, 545-548.

Rosado, J. L., Solomons, N. W., Lisker, R. \& Bourges, H. (1984). Enzyme replacement therapy for primary adult lactase deficiency. Gastroenterology 87, 1072-1082.

Saavedra, J. M. \& Perman, J. A. (1989). Current concepts in lactose malabsorption and intolerance. Annual Review of Nutrition 9, 475-502.

Scrimshaw, N. S. \& Murray, E. B. (1988). The acceptability of milk and milk products in populations with a high prevalence of lactose intolerance. American Journal of Clinical Nutrition 48, 1086-1098.

Seeman, E., Wahner, H. W., Offord, K. P., Kumar, R., Johnson, W. J. \& Riggs, B. L. (1982). Differencial effects of endocrine dysfunction on the axial and appendicular skeleton. Journal of Clinical Investigation 69 , $1302-1309$.

Slemenda, C. W., Christian, J. C., Hui, S., Fitzgerald, J. \& Johnston, C. (1991). No evidence for an effect of lactase deficiency on bone mass in pre- or postmenopausal women. Journal of Bone and Mineral Research 6, 1367-1371.

Smith, T. M., Kolars, J. C., Savaiano, D. A. \& Levitt, M. D. (1985). Absorption of calcium from milk and yogurt. American Journal of Clinical Nutrition 42, 1197-1200.

Strocchi, A. \& Levitt, M. D. (1992). Factors affecting hydrogen production and consumption by human fecal flora: the critical role of hydrogen tension and methanogenesis. Journal of Clinical Investigation 89, $1304-1311$.

Vigorita, V. J., Lane, J. M., Suda, M. K. \& Nelkin, M. (1987). Differences between lactase deficient and nonlactase deficient women with spinal osteoporosis. Clinical Orthopaedics and Related Research 215, $248-253$.

Weinstein, R. S. \& Bell, N. H. (1988). Diminished rates of bone formation in normal Black adults. New England Journal of Medicine 319, 1698-1701. 